\title{
Editor's Report for Volume 126 (2012)
}

Mailing dates for issues in volume 126:

(1) 3 October 2012

(2) 4 December 2012

(3) 25 January 2013

(4) 23 May 2013

A summary of the distribution of memberships in the Ottawa Field-Naturalists' Club and subscribers to The Canadian Field-Naturalist for 2012 is provided in Table 1. The number of articles and notes in Volume 126 is summarized in Table 2 by topic; totals for book reviews and new titles is given in Table 3; and the distribution of content by page totals per issue is provided in Table 4. Manuscripts (excluding book reviews, notices and reports) submitted to The Canadian FieldNaturalist totalled 67 in 2012. Of these, 60 were accepted for publication, and 31 were published in volume 126, along with 18 manuscripts submitted in 2011 and revised in 2012, 1 manuscript submitted in 2010 and revised in 2012, and 1 manuscript submitted in 2009 and revised in 2012. A total of 20 Articles, 25 Notes, 5 Tributes, and 1 Essay were published in 2012.

Trina Rytwinski, Assistant Editor, edited content and acted as an Associate Editor; Elizabeth Morton proofed and edited manuscripts; Wendy Cotie typeset galleys and corrections for page proofs and created pdfs; Roy John, Book Review Editor, requested books for review, selected reviewers, edited submitted reviews, and prepared the new titles listings; Jay Fitzsimmons, Journal Manager, managed financial accounts, issue mailing, and requests for back issues, conducted journal promotion through Twitter and other means, and provided digital content to subscribers. Leslie Cody prepared the Index with proofreading by Frank Pope. Sandra Garland, webmaster of the Ottawa Field Naturalist Club, posted tables of contents, abstracts, and pdfs on the CFN section of the OFNC website. Our Associate Editors managed manuscripts, provided reviews and recommendations, and guided authors through the revisions process. The Publication Committee, chaired by Dan Brunton and consisting Paul Catling, Jay Fitzsimmons Sandra Garland, Tony Gaston, Karen McLachlan
Hamilton, Elizabeth Morton, Frank Pope, and Jeff Saarela effectively guided the operation of the journal. I am indebted to our very dedicated and effective team.

The following Associate Editors managed and assessed manuscripts submitted to the CFN: Associate Editors: R. Anderson, Canadian Museum of Nature, Ottawa ON (1); W. B. Ballard (deceased), Texas Tech University, Lubbock, TX (2); C. Callaghan, Luskville QC (9); P. M. Catling, Agriculture and Agri-Food Canada, Ottawa ON (3); F. R. Cook, Emeritus Research Associate, Canadian Museum of Nature, Ottawa ON (6); A. J. Erskine, Sackville NB (7); T. S. Jung, Yukon Government, Whitehorse YT (2); D. F. McAlpine, New Brunswick Museum, St. John NB (3); D. W. Nagorsen, Mammalia Biological Consulting, Victoria BC (6); C. Renaud, Canadian Museum of Nature, Ottawa ON (2); T. Rytwinski, Carleton University, Ottawa ON (5); J. Saarela, Canadian Museum of Nature, Ottawa ON (2).

The following referees reviewed manuscripts submitted to the CFN (number of manuscripts reviewed $>1$ in parentheses): W. B. Ballard (deceased), Texas Tech University, Lubbock, TX; M. Barclay, University of Calgary, Calgary AB; P. Beier, Northern Arizona University, Flagstaff, AZ; L. Belanger, University of Laval, Quebec QC; D. Boyd, USFWS, Helena, MT; C. D. Bird, Erskine AB; J. Bowman, Ontario Ministry of Natural Resources, Peterborough ON; M. Brigham, University of Regina, Regina SK; D. Brunton, Brunton Consulting, Ottawa ON; R. Brooks (retired) University of Guelph, Guelph ON; J. Burns (retired) Royal Alberta Museum; T. Caro, University of California, Davis CA; P. M. Catling, Agriculture and Agri-Food Canada, Ottawa ON (2); B. Coad, Canadian Museum of Nature, Ottawa ON; A. Desrochers, University of Laval, Quebec QC; T. Diamond, University of New Brunswick Fredericton NB; M. Docker, University of Manitoba, Winnipeg, MB; A.J. Erskine, Sackville NB; B. Fenton, University of Western Ontario, London ON; G. Forbes, University of New Brunswick, Fredericton NB A. J. Gaston, Environment Canada, Ottawa ON; J. Gilhen, Nova Scotia Museum of Natural History, Halifax, NS;

TABLE 1. The 2012 circulation of The Canadian Field-Naturalist (2011 in parenthesis). Compiled by Jay Fitzsimmons from mailing list for 126(4).

\begin{tabular}{|c|c|c|c|c|c|c|c|c|}
\hline Subscriber Type & \multicolumn{2}{|c|}{ Canada } & \multicolumn{2}{|c|}{ USA } & \multicolumn{2}{|c|}{ Other } & \multicolumn{2}{|c|}{ Total } \\
\hline \multicolumn{9}{|l|}{ Memberships } \\
\hline Family \& Individual & 89 & (101) & 8 & (8) & 1 & (1) & 98 & (110) \\
\hline \multicolumn{9}{|l|}{ Subscriptions } \\
\hline Individual & 81 & (93) & 30 & (34) & 3 & (4) & 114 & (131) \\
\hline Institutional & 122 & $(120)$ & 164 & (179) & 27 & (23) & 313 & $(322)$ \\
\hline Total & 292 & $(314)$ & 202 & $(221)$ & 31 & $(28)$ & 525 & $(563)$ \\
\hline
\end{tabular}


TABLE 2. Number of research and observation articles and notes published in The Canadian Field-Naturalist, Volume 126 , by major field of study.

\begin{tabular}{lccr}
\hline \hline Subject & Articles & Notes & Total \\
\hline Mammals & 8 & 12 & 20 \\
Birds & 7 & 7 & 14 \\
Amphibians and Reptiles & 2 & 2 & 4 \\
Fish & 2 & 0 & 2 \\
Plants & 1 & 3 & 4 \\
Insects & 0 & 1 & 1 \\
\hline Total & & & 45 \\
\hline
\end{tabular}

TABLE 3. Number of reviews and new titles published in the Book Review section of The Canadian Field-Naturalist, Volume 126, by topic.

\begin{tabular}{lcc}
\hline \hline & Reviews & New Titles \\
\hline Zoology & 20 & 43 \\
Botany & 2 & 5 \\
Environment & 7 & 2 \\
Miscellaneous & 5 & 25 \\
Children & 2 & 3 \\
\hline Total & 36 & 78 \\
\hline \hline
\end{tabular}

P. Gregory, University of Victoria, Victoria BC (2); D. Gummer, Parks Canada, Calgary AB; A. Gunn (retired), Government of Northwest Territories, Yellowknife NWT; D. Gustine, USGS, Anchorage AK; T. Herman, Acadia University, Wolfville NS; G. Hilchie, University of Alberta, Edmonton AB; J. Hodson, University of Laval, Quebec, QC; C. Hoodicoff, Associated Engineering, Vernon BC; S. Houston (retired), University of Saskatchewan, Saskatoon, SK; H. Jaqmain, University of Laval, Quebec QC; M. Johnson, Global Wildlife Resources, Bozeman, MT; V. Johnston, Environment Canada, Yellowknife NT; D. Klein, University of Alaska Fairbanks AK; T. Kinley, Parks Canada, Revelstoke BC; E. L. Koen, Trent University, Peterborough, ON; N. Kondla, Genelle, BC; B. Lim, Royal Ontario Museum, Toronto ON; D. F. McAlpine, New Brunswick Museum, St. John NB; J. McRoberts, Texas Tech University, Lubbock, TX; W. Meshaka, State Museum of Pennsylvania, Harrisburg, PA; G. Michener, University of Lethbridge, Lethbridge AB; N. Mundahl, Winona State University, Winona MN; J. O. Murie (retired), University of Alberta, Edmonton AB (3); G. Mowat, British Columbia Ministry of Forests, Lands and Natural Resource Operations, Nelson BC; J. Myers, University of British Columbia, Vancouver BC; D. W. Nagorsen, Mammalia Biological Consulting, Victoria BC; F. Osorio, University of British Columbia, Vancouver BC; B. Patterson, Ontario Ministry of Natural Resources, Peterborough ON; J. Peek, University of Idaho; R. Poulin,
TABLE 4. Number of pages per section published in The Canadian Field-Naturalist, Volume 126 (2012), by issue.

\begin{tabular}{|c|c|c|c|c|c|}
\hline & \multicolumn{4}{|c|}{ Issue } & \multirow[b]{2}{*}{ Total } \\
\hline & 1 & 2 & 3 & 4 & \\
\hline Articles & 27 & 59 & 28 & 39 & 153 \\
\hline Notes & 33 & 16 & 28 & 20 & 97 \\
\hline Book Reviews* & 18 & 10 & 5 & 13 & 46 \\
\hline \multicolumn{6}{|l|}{ News and Comment, } \\
\hline Reports** & 3 & 4 & 13 & 4 & 24 \\
\hline Tributes & 7 & 8 & 15 & 0 & 30 \\
\hline Index & - & & & 13 & 13 \\
\hline Advice to Contributors & & $\overline{3}$ & $\overline{3}$ & 3 & 9 \\
\hline Total & 88 & 100 & 92 & 92 & 372 \\
\hline
\end{tabular}

*Includes reviews and new titles listings

** Includes CFN Editor's report, Minutes of the OFNC

Annual Business Meeting, and OFNC Awards report.

Royal Saskatchewan Museum, Regina SK; G. Proulx, Alpha Wildlife Research and Management, Sherwood Park AB; M. Pybus, Alberta Environment and Sustainable Resource Development, Edmonton, AB; J. Ray, Wildlife Conservation Society, Toronto ON; R. L. Rausch (deceased), Professor Emeritus, University of Washington, Seattle WA; C. Renaud, Canadian Museum of Nature, Ottawa ON; M. Reudink, Thompson Rivers University, Kamloops, BC; G. Robertson, Environment Canada (2); R. Rosatte, Ontario Ministry of Natural Resources, Peterborough ON; J. Saarela, Canadian Museum of Nature, Ottawa ON; H. Schwantje, British Columbia Ministry of Forests, Lands and Natural Resource Operations, Victoria BC; F. Scott Acadia University, Wolfville NS; D. Seburn, Ottawa ON (2); C. Sheviak, New York State Museum, Albany NY; S. Sobek-Swant, Ryerson University, Toronto ON. Sweanor, Wild Felid Research and Management Association; R. Vallender, Environment Canada, Gatineau, QC; K. Vanderwolf, New Brunswick Museum, St. John NB; R. Virtanen, Oulu University, Oulu Finland; K. Weibe, University of Saskatchewan, Saskatoon, SK; R. Weir, British Columbia Ministry of Environment, Victoria BC; W. Weller, Hydro One, Niagara Falls ON; J. Whitaker Jr., Indiana State University, Terre Haute, Indiana.

The journal was printed at Gilmore Printers, Ottawa. Thanks to Gilmore for overseeing production and printing. I am grateful to President Ann McKenzie and Council of the Ottawa Field-Naturalists Club for their support of the journal. I am also grateful to all of the individual subscribers and authors who encouraged our team as we strive to provide a high-quality scientific journal on natural history. Finally, I thank my family for being patient and supportive throughout many evenings and weekends of working on the journal.

CAROLYN CALLAGHAN Editor 